The Geneva Papers on Risk and Insurance, 15 (No. 57, October 1990), 372 - 389

\title{
Fourth Geneva Lecture: Corporate Strategy of European Insurers*
}

\author{
by Prof. Dr. Dieter Farny**
}

\section{1. "European Insurers"}

"Europe" and "1992" are not only slogans with programmatic and symbolic contents. The vision of a unified Europe and the dawning reality of unified European markets lead one to ask whether the corporate strategy of insurers can still be at all national in the future, or whether it will inevitably have to take on a European dimension. To put it another way: in future will there just be one European insurance market with "European insurers", or will there still be national markets with insurers who operate within national boundaries?

For the moment, any answer to this question must be purely speculative. But there is a plausible hypothesis based in part on empirical studies among European insurers and also reinforced to some extent by changes which have actually taken place in the more recent past. According to this hypothesis, polarisation of the types of insurers fund will occur.

- At one extreme will be the (very) large insurers who operate in a fairly general way on a Europe-wide or worldwide basis.

- At the other extreme will be the small or medium-sized insurers that operate nationally, perhaps even only locally, and will continue to do so. Specialisation in a limited area of operation is often followed by specialisation in specific business segments, for example in individual classes of insurance or - and this is becoming increasingly important - in individual groups of customers.

But even just this polarisation theory gives rise to considerable disquiet as far as corporate strategy is concerned. Many insurers in Europe who currently have an indistinct image must decide whether they want to make the substantial effort required to join the ranks of the large general insurers operating Europe-wide or worldwide, or whether they want to become increasingly specialised and confine themselves to regional markets or other defined market segments.

* Held in Madrid, May 10, 1990. Chairman: Mr. Felix Mansilla, President of UNESPA (Spanish Federation of Insurance Companies).

** Director of the "Institut für Versicherungswissenschaft", University of Cologne, and VicePresident of the Geneva Association. 
If this theory is correct, it is quite possible to answer in fairly broad terms the question asked at the outset. In future there will be not only "European insurers" in the sense of very large companies operating internationally, but also national insurers which continue to work a limited market and in so doing, increasingly enter into competition with the "European" insurers.

\section{General background to corporate strategy}

Against what sort of a background will the corporate strategy of European insurers take place? Will they work under completely reshaped economic, legal and social conditions, or will their current operating conditions and principles cssentially continue to apply? Does "Europe 1992" mean a spontaneous mutation or rather a moderate evolution? Do insurers need a "new corporate strategy"?

\subsection{The single European insurance market}

The most important change ahead is the creation of a single European market in insurance with effect from 1993, through the realisation of freedom of establishment and freedom of services. The individual de jure and de facto procedures are less important for the future shape of the single insurance market than the underlying philosophy. The ideal form of the single insurance market would be as follows: the insurance markets in the twelve EC countries together constitute a unified, "common" overall market with no national borders in which insurers, insurance customers and insurance brokers can transact their business under the same competitive conditions, regardless of their national locations. This original concept of the EC would require the harmonisation of all operating conditions, particularly in the areas of insurance contract law, insurance supervisory law, taxation and competitition law - in short harmonisation of all the market regulations too. This philosophy of harmonisation, resulting in a truly "common market" has for the most part failed. Consequently, in the last few years a new philosophy has sprung up. This involves eliminating the boundaries of national insurance markets, chiefly through the freedom of services, thus making it possible to transact insurance business across borders without the conditions for competition in the individual national markets being first harmonised. The twelve national market systems, each with its own de jure and de facto conditions, shall enter into competition with each other. The idea is: Not competition based on the same pre-conditions; rather: competition itself shall lead to the same pre-conditions through a lengthy process of adaptation.

There is certainly some doubt as to whether this works, that is to say whether competition can lead to good results under unequal conditions. Problems arise for insurers who in the course of international competition come across competitors working under more favourable - which is to say less regulated - conditions. But problems also arise for insurance customers, who in the case of cross-border business have to contend with different levels of consumer protection. The current trend is to try and find a solution to these problems by making the single insurance market initially just for insurance business involving large commercial customers and risks, while national regulations in the policy-holders' favour will continue to apply in the case of business involving private customers, so that freedom of services in this area of business will apply only to a limited extent. 
From these facts it is possible to draw two initial important conclusions with regard to the corporate strategy of European insurers:

- Despite freedom of establishment and freedom of services, national insurance markets will persist for a long transitional period and retain their individual legal, economic and social characteristics. These involve above all product design, marketing and service systems, and the relationship between the insurance industry and the banking industry the latter especially with an eye to life assurance. To give an example, in Spain in particular the way that insurance and banking intertwine has an entirely different structure from that found in, say, the United Kingdom or Germany. Corporate strategy has to accept this and acknowledge and take account local conditions.

- The corporate strategy of European insurers as regards business with industrial and commercial companies is fundamentally different from that with private households. There is more freedom of scope in industrial and commercial business, which means that the possibilities for corporate strategy are much more extensive than is the case where private customers are concerned.

Attention also has to be drawn to the latest political and economic developments in Europe. For about six months now, insurers - especially German and Austrian ones have not only had to make decisions about their future activity in the EC but have also had to consider the question of expansion into the countries of Eastern Europe. The market potential there is particularly large, though of course there are still considerable legal and practical difficulties, and the subject is therefore not yet ripe for a sound assessment.

\subsection{Trends affecting insured risks}

A second important basic factor affecting the corporate strategy of European insurers is the trend in insured risks or risks which are to be insured. Seen from an international point of view, several trends can be identified.

The number of large and very large losses and the claim amounts payable as a result are continously rising. This is especially true of risks involving large companies operating internationally in industry, transport and trade. The classes of business affected are, in particular, Fire, Business Interruption, Engineering, Marine and Liability. The reasons for this are to be found partly in the technical sphere and partly in the social sphere - the latter being of growing importance. In particular, it should be noted that certain circumstances are increasingly being recognised and assessed as losses and that more damage compensation systems are being demanded, as is the case with environmental impairment losses, for example. Many losses of this type can no longer be treated as "national" but have by their nature acquired an international dimension. This becomes particularly obvious in the case of large multinational companies, owing to their worldwide logistical structure: small individual losses may lead to large consequential losses. Remarkably, an internationally uniform trend is also to be seen in the large and very large losses to be expected from natural hazards, chiefly on account of the increasing accumulations of persons and property in a confined area.

It is often difficult to ascertain whether such large and very large losses are due to pure random processes or to changes in the "cause-of-loss" systems. There is, however, 
every reason to believe that "cause-of-risk" systems are being destabilised at this time, which is to say that they are changing dynamically. The reasons for this are to be found in technical developments, but increasingly also in social attitudes and values held with respect to risks, losses and claims financing. In this connection, many examples can be found in the areas of products liability and environmental impairment liability.

The developments affecting risks raise quite difficult questions with regard to corporate strategy, for insurers are forever coming upon limits to insurability because the risks to be assumed, the premiums obtainable and the available security funds are not in the right proportion to each other. The problems are aggravated by the fact that risk trends throughout Europe and worldwide are correlated rather positively and because at the same time customers' readiness to arrange professional insurance of small and medium-sized risks is declining. On top of this, more and more direct insurers are pulling out of the business sector comprising large and very large risks and are specialising in private-customer business. Because of this, the ability to balance the risks in portfolio is declining, and every available technique must be used to spread risks worldwide. These demands naturally give direct insurers a certain incentive to internationalise their business activity; but first and foremost they represent a challenge to the capabilities of worldwide reinsurers. From these problems it can be seen that the frame of the EC is probably much too restricted to cope with the "new risks".

\subsection{Behaviour of policyholders}

The corporate strategy of European insurers will essentially depend on whether the insurance customers see their insurance business as being "national" and "local" rather than international. The empirical findings so far do not give any clear answer to this, but a few trends have been observed.

One fundamental fact to emerge is that there is no standard type of insurance customer. In the first place, completely different national attitudes are in evidence - for example in basic risk management philosophies, or in preference of certain forms of insurance cover concepts, or in particular marketing and service methods. And secondly, customer behaviour is completely different, depending on whether these are large industrial firms, often operating internationally, or small or medium-sized commercial enterprises, or else private households. Firms which themselves operate internationally, be it through production facilities abroad or through a high level of export activity, are showing increasing willingness and ability to internationalise their insurance business. Since the single European market will lead to a restructuring of industrial productions sites, where the insurance of industrial risks is concerned it is only to be expected that the risks - and therefore also the insurance covers needed for them - will become more international in character. This is a very important factor for the development of Community-wide industrial and commercial insurance business, which is something that will be further strengthened by the activity of international insurance brokers.

In the case of small enterprises and private households, a quite different situation exists. These insurance customers are characterised worldwide by two distinctive features: their knowledge of risks and insurance is meagre, and their demand behaviour is not so much active and cognitive as rather passive and habitual. In other words: they do not manage their insurance business professionally on the basis of rational calculations, but 
they buy policies in a conventional way from familiar insurers operating as close by as possible. They expect considerable advice and service in their own locality. This pattern of behaviour also explains the well-known slogan that "all business is local", which is certainly of particular importance where business with private customers is concerned.

These observations on the behaviour of insurance customers lead to two conclusions. Firstly, in Europe international insurance business will come about initially predominantly for large industrial customers and those operating internationally, and to a much lesser extent - or not at all - for small commercial and private customers. Secondly, any insurer wanting to be fully active in the markets of individual countries, and in particular wanting to enter the market for business with private households, will have to be present locally. Or, to put it another way: insurance business with private customers involving free crossborder services can only be developed to a rather minor extent unless there is a fundamental change in the pattern of customer behaviour currently seen.

\subsection{Insurers' activities so far}

Without a doubt, even today the creation of a single insurance market from 1993 onwards has already had a major initial effect on insurers' activities. The process of creating a distinctive image either as a large, general European insurer or as a rather more specialised national insurer has already been under way for some time. The list of relevant activities changes daily: the setting up of branches and subsidiaries abroad, the cross-border buying and selling of companies, the establishment of new cooperation agreements - all these have become almost commonplace items of news.

These events can be corroborated by an empirical study which the Geneva Association and the Institute for Insurance Studies of the University of Cologne carried out in 1988 by means of a survey of European insurers. According to the opinions expressed, roughly a quarter of all the insurers in Europe expect to internationalise their business activity. The prime reason for doing this will be to follow the international operations of their customers. Moreover, it is chiefly growth targets and not so much profit targets that are being pursued. Measured against such targets, within the EC the Spanish market is seen as the most attractive, particularly on account of the high growth rate of the Spanish economy. The insurance markets of Italy and France range second and third on the attractiveness scale. The insurers expected to make the most effort to expand in the European markets are those of the UK, Germany and France. The preferred strategies for entering the new markets mainly involve establishing a local presence and adapting to market practice in the country of operation. Free cross-border services are considered to be of only secondary importance - which once again confirms the principle that "all insurance business is local".

\section{Contents and options of the corporate strategies of European insurers}

\subsection{Survey}

Corporate strategy means controlling an insurance company by setting targets in advance and selecting suitable economic activities, that is to say the programmes and the methods applied. The sum of each of the activities pursued is understood as a portfolio of business segments. The individual business segments in which a company operates can be delimited in quite different ways, and in particular: 
- according to products, that is to say according to the classes of business transacted and if necessary also according to other financial services;

- according to customers of customer groups, especially the delimitation of industrial and commercial business form private-customer business;

- according to regions, for instance by individual national markets or parts thereof;

- according to procedural techniques, for instance according to the marketing procedures applied.

The controlling task of corporate strategy is not only short term and subtly differentiated; it is much more important in the long term, conceptionally, in relation to the company as a whole, and taking account of future environmental conditions. This leads to a distinction between operational and strategic corporate policy. Because of the imminent major changes in Europe, the strategic issues of corporate policy are currently attracting most interest. Here it is a matter of developing overall objectives - a kind of corporate philosophy - for the coming years and decades, of determining potentials in the markets which are being worked or which could be worked, and also of determining one's own corporate potential, with all the in-house strengths and weaknesses. From the overall objectives and the corporate and market potentials, the strategic directions for the thrust of future activities are then derived.

\subsection{Important images of the strategic corporate policy of European insurers}

The strategic unrest among insurance companies in Europe already mentioned at the outset, triggered not only by the imminent single market in insurance but also by the single markets for all other material goods and services, is virtually challenging each individual insurer to develop for itself a corporate philosophy which will be valid in the long term. Such a philosophy then becomes the guiding principle for all strategic decisions and the perspective for the future. Without such a philosophy a rational corporate policy would just not be possible. Insurers would take spontaneous, uncoordinated individual decisions; they would not steer systematically towards a long-term goal but would zigzag according to short-term conditions. What then are such conceivable philosophies and overall objectives for the development of medium- and long-term strategies? As the ideal, the following possibilities in particular exist:

(1) The philosophy of "internalisation" contrasts with the philosophy of "staying national". With all the euphoria prevailing with regard to the single insurance market in the EC and the resulting possibilities, it should not be forgotten that most insurers in Europe will remain national companies. It therefore seems reasonable to clearly articulate this objective as the corporate philosophy and to orientate all activities to this spatial limitation of business activity. The philosophy of "internalisation" offers various ways to go. The two most important basic attributes are "to follow national clients abroad with their international risks" and "to break into new, foreign markets". The first of these is based on a limited philosophy of internationalisation, the second on an unlimited one.

(2) The differentiation into "aggressive philosophies" and "defensive philosophies" shows a similar dual split. Being aggressive means conquering new market shares in markets already worked and in new markets. Being defensive, on the other hand, means defending one's own market shares against attackers. It would be a serious mistake to regard aggressive strategies as being effectively free-market and commercial in nature 
while disqualifying defensive strategies. All insurers have only limited resources available for working their markets. If they have market shares which are large, stable and profitable, their resources should be devoted primarily to looking after and maintaining these, with the winning of new market shares taking second place. Otherwise there is a risk of resources being abused to win new, perhaps less attractive market shares, while at the same time attractive market shares are lost to competitors for lack of resources. There are many examples of cases where this has actually happened.

(3) Again, seen from a different point of view, the basic corporate philosophies can be interpreted as striving for growth and size and neglecting profit targets, or as striving for profits while neglecting growth and size targets. The competition between growth and profit targets applies in particular in the short to medium term. There are many lines of argument which can be used to show both theoretically and empirically that strong expansion leads to falls in profits and that, conversely, an insurer's profits can be improved by limited and, in particular, selective growth. One can therefore also define this alternative with the slogan "quantity before quality" versus "quality before quantity".

(4) A final way of looking at the situation consists in seeing the basic philosophy as the choice between generalisation and specialisation. General insurers want to operate in many countries and transact all classes of business with all classes of customer. Specialists, on the other hand, confine themselves regionally either with regard to the insurance products they offer or with regard to individual groups of customers. Polarisation towards either generalisation or specialisation is expected to increase among European insurers.

\subsection{Decisive factors for overall corporate strategies}

What factors are of particular importance when choosing a general corporate strategy? Once again, a distinction has to be made between the external factors of the markets and business segments and the internal factors within the company.

The most important market factors are generally summarised under the heading "market attractiveness" and above all include the individual size of the markets and their potential for further growth, the present profit situation and future profit expectations, and also - as the counterpart to these prospects - the special risks of the individual markets arising from insurance business, from investment business, and from the overall legal, economic and social situation. Thus, the corporate strategy of European insurers is increasingly dependent on whether they consider the presently worked market segments more attractive than those which are to be tackled due to the internationalisation, growth and generalisation trends. This leads to an important conclusion: the corporate strategy of European insurers will essentially be determined by the changes and developments to the attractiveness of their regular markets compared to the new markets which could possibly be included in their programmes. For this reason there cannot and will not be a uniform corporate strategy of European insurers. Insurers in countries with large, growing and profitable markets will strive less to break into new markets than those in countries with stagnating or unprofitable markets. Conversely, the expansion trend in markets with high growth potentials and good profit expectations will be much stronger than that in markets with limited growth and low profit expectations. This is one of the reasons why the Spanish 
insurance market in particular is currently arousing such interest among European insurers. It is considered very attractive because the dynamic Spanish economy promises high growth rates also in insurance business; the Italian and Portuguese markets are expected to behave in a similar way.

In the individual companies, the most important internal factors affecting long-term corporate strategy will be determined by the resources available or obtainable. Any expansion into new business segments requires the use of resources, and this is especially true in cases of access to completely new markets.

These resources primarily involve staff and the know-how they represent, and also the capital required for financing investment in new business sectors. Personnel capacity and know-how are mostly limited, especially when it comes to strategies for foreign expansion; it is often amazing how poorly informed insurers are about markets in other countries an indication of the great significance of national and local peculiarities. Capital resources are frequently in short supply, because to finance expansion investment requires mostly equity capital - most countries' investment regulations do not allow underwriting reserves to be used to finance entry into new business segments because the profitability of such investments is uncertain.

The question of resources naturally also has to be seen in relation to the size of the individual companies. Large insurers generally possess more and better personnel resources - for example staff for carrying out market research or for monitoring foreign markets. Large companies also usually have much more capital available for investment, particularly if they have access to the capital market. In this respect, insurers without access to the organised capital markets - most mutual insurance companies, for example - have a structural disadvantage.

So, once again, assessment of the overall corporate strategies possible does not produce a uniform picture. There is no doubt that a number of large insurers with a good supply of resources will expand into new business segments. But there will no doubt also be many insurers who, for lack of resources, will not be able to do this or, because of the attractiveness of their own traditional markets, will in any case not want to. It is therefore not to be expected that all European insurers will follow the ideas of "internationalisation - attack - growth and expansion - generalisation". Rather, many insurers will simply make a conscious and more vigorous effort to improve their position in their traditional markets.

\subsection{The main strategies}

The main strategies should be derived from the overall philosophy decided on for corporate policy. Here it is a matter of the internationalisation, customer, product and procedural strategies installed in order to pursue the overall objectives.

\subsubsection{Internationalisation strategies}

Where internationalisation is the main guiding principle of corporate policy, appropriate strategies for the expansion of business activities must be defined. For this there are two basic principles available, namely to export insurance cover from the home country with the help of freedom of services, or to set up places of business in the country of operation. This alternative can also be described using the terms "tele-business" as opposed to "on-the-spot business". 
According to all the theoretical considerations and practical experience, there is no doubt that insurance business is first and foremost local business, and that it is therefore a better idea to buy or establish subsidiaries or at least to set up offices for carrying on business in the countries of operation. The national and local character of isurance business arises from its integration in the relevant economic and legal system and from the often rigid conduct of the customers. And not least, certain procedures involved in the transaction of insurance business must necessarily be carried out on the spot, that is to say at the customer's premises or in the vicinity of the risk - for example the inspection of risks, and loss settlement. Despite the single insurance market in the EC, each of the markets in the twelve member countries will largely retain their national and local characteristics. A successful strategy abroad therefore presupposes assimilation to the relevant market system. However, the intensity with which integration and assimilation take place may vary. For this reason, most on-the-spot operations will be introduced in different ways, for example by means of cooperating and fronting partners, through brokers or agencies, newly-established or acquired subsidiaries, or through a company's own branches, representatives and offices.

On the basis of all known arguments, the prospects for the export model - that is to say cross-border insurance business - do not look too good. Which even raises the question as to whether the enormous efforts involved in introducing de jure and de facto steps to create freedom of services within the EC is not perhaps a great waste, considering the meagre results which are to be expected in direct insurance business. Freedom of services can facilitate cross-border insurance business with large professional clients; it can also favour international concepts of cover for industrial clients operating internationally, since their "familiar" insurers no longer have to have admitted subsidiaries in all the countries where the risks are located. With very intelligent and active clients there may even exist some cross-border business in the private-customer sector. But all these market segments are relatively small, so the export model cannot form a general basis for the internationalisation of insurers' activities. Within the common single insurance market of the EC the motto "insurance business is local business" will therefore continue to apply, and internationalisation strategies with no local presence will not be very successful.

\subsubsection{Customer strategies}

A second basic strategic decision concerns the customer segments to which insurance cover is offered. Developments in the EC market lead one to expect that, insurance business with industrial and commercial enterprises will very quickly be deregulated, while business with private customers will continue to be regulated by (non-standard) national supervisory systems. Consequently, in the case of industrial and commercial business, it will be possible to have completely free market activity, for example with regard to product design and premiums, whereas private-customer business will continue to be subject to market-policy restrictions. For insurers, this means that they have to decide whether to operate in both business segments (but then with different market strategies) or whether it is preferable to specialise in either industrial and commercial business or private-customer business. Such a restriction would no doubt make it easier to build up a uniform corporate image and to opt for uniform and consistent product and price policies.

All-round insurers, on the other hand, will in future increasingly have to be able to develop a split personality, namely as extremely competition-oriented insurers in industrial 
and commercial business, and as insurers with limited freedom - depending on the relevant supervisory set-up - in connection with private-customer business. The dual image required is extremely difficult to handle and can only be achieved with the help of suitable forms of internal organisation. At all events, it is to be expected that the principles shaping these two business sectors will increasingly diverge from each other so that, in this respect too, polarisation must be reckoned with.

\subsubsection{Product strategies}

The new freedoms in the single insurance market of the EC will also lead to new strategies in product design. The traditional forms of insurance cover are predominantly related to individual risks. This has led to a highly differentiated system of classes of insurance. Clients requiring more than one kind of insurance cover for several risks therefore generally have to arrange numerous individual policies which cannot easily be coordinated to one overall protective concept. Many clients are therefore of the opinion that having different kinds of insurance to deal with an integral problem of protection is not the ideal solution. Corporate strategy is therefore increasingly expected to go in the direction of multi-risk or "all-risk" covers, possibly also prompted by corresponding forms of products in America. This trend is not without its problems from the insurers' point of view. All conventional underwriting is based on the insurance of precisely defined individual risks as only for these ones the "cause-of-loss" systems are recognisable, the claims expectation values and thus the necessary premiums can be assessed with sufficient accuracy, and the techniques for balancing risks - including reinsurance - can be used with the necessary unambiguity. The features of multi-risk or "all-risk" covers are exactly the opposite: the "cause-of-loss" systems are vague, premium calculation is inexact, and the techniques for balancing risks become more difficult. The corporate strategy of insurers therefore has to find a reasonable compromise between clients' wishes on the one hand and the techniques available for producing the insurance cover on the other. Moreover, this does not apply only to industrial and commercial business, but more and more also to business with private customers, where multi-risk covers are increasingly being discussed.

Another decision relating to product strategy concerns the degree of individualisation or standardisation of insurannce cover. Without a doubt, clients' wishes for insurance products to be adapted to real needs tend to be growing, and this goes for both, industrial clients and private customers. This individualisation concerns not only the form of the insurance cover when the contract starts, but also its adaptation to the client's changing risk situations in the course of time. Examples of this are covers with high deductibles encompassing several classes of business, including in connection with self-insurance and captive concepts, or life policies with highly individual and variable saving arrangements. In the long term, standardised insurance products will only be able to satisfy standardised basic requirements in mass business with private customers.

For the large, general insurers, the strategy of individual, adaptable insurance products is very much more difficult than for the small specialised insurers. Here, a particularly attractive market segment opens up for special insurers operating in a limited area and range, and whose image is determined less by size and universality but more by the philosophy of individual, very high-quality (and correspondingly expensive) insurance products. The expectations for growth to be satisfied are not so high but good profits can be expected. 
A final question with regard to the corporate strategy of European insurers concerns entry into the "one-stop financial services" concept, that is to say the transaction of both insurance and banking business. This is not so much a "European" question, however, because the de jure and de facto conditions for one-stop financial business and customer behaviour differ from country to country. This also applies to the links existing between banks and insurers, which differ from each other in the individual countries. The view which predominates is that one-stop financial services are only attractive as far as business with private customers is concerned, and this is the business which is least accessible to the European dimension. This point of view will therefore not be dealt with further here.

\subsubsection{Procedural strategies}

The procedures in insurance business relate on the one hand to the balance of risks and on the other to the handling of business with respect to customers. The most important underwriting procedures for the balancing of risks are the portfolio mix according to features of quantity, quality, space and time, reinsurance policy and solvency policy. In the case of internationalised business activity, it is not so much a matter of the balance of risks in the portfolios in the individual countries of operation but rather of that in the insurer's portfolio as a whole. This balance of risks may possibly have to be achieved by means of special reinsurance business though, if legally independent subsidiaries are active in the individual countries of operation. Whether internationalisation leads to a better balance of risks essentially depends on whether loss and premium trends are correlated positively or negatively in the individual markets, or whether they are independent of each other. Apart from natural hazards, the speculation which currently applies is that of a strong positive correlation between business trends; but in that case the balance of risks is not fundamentally improved by internationalisation.

In view of the trend towards large and very large losses, reinsurance policy is increasingly gaining in importance. A clear trend in reinsurance strategy from proportional to non-proportional covers can be seen. With non-proportional reinsurance the ceding company is able to stabilise its random burden of losses better than with proportional covers, the advantages of which lie above all in risks of change. However, an increase in non-proportional covers makes it more difficult to achieve a balance of risks among the reinsurer's portfolios because the volume of business decreases and the claims distribution gets bigger. Reinsurers will consequently have to ask for increasingly higher premiums for non-proportional covers in order to obtain the necessary safety loadings and to be able to build up reserves for the balance of risks over time. This example shows that particularly efficient reinsurance solutions cannot be cheap.

In future, greater importance will be attached to solvency policy, namely the way that equity capital is made available for settling possible losses. All international discussions on the deregulation of insurance markets suggest that the increasing ruin probability of insurers as a result of growing competition may be compensated by higher amounts of company capital. Without a change in the law, of course, an increase in the statutory minimum solvency margin in the EC is not possible at all. Nevertheless, equity capitalisation will increasingly be a sign of an insurer's security and thus of its product - insurance cover. The care of equity capital including all hidden reserves is therefore an important factor of a market-related corporate strategy. The true equity capitalisation of insurers operating 
internationally will be more clearly identifiable than previously in the forthcoming world annual balance sheets and accounts. Care of the equity capital base presupposes that profits will be made; for equity capital is created either directly through the retention of profits or against the promise of dividends drawn from the capital market. Solvency policy therefore frequently leads to the limitation of expansion efforts, with unclear or poor profit expectations.

The technical procedures for transacting insurance business give rise to far fewer problems. It must be assumed though that the operating and marketing procedures of insurers in the individual countries are very different because they are based on traditional customer behaviour patterns which are very difficult to change. This is especially true of marketing procedures, for example the use of independent brokers, of representatives or other salespersons tied to particular insurers, and finally of central direct selling without intermediaries. Decisions on marketing policy allow two developments to be expected. Firstly, many insurers will try to use several marketing procedures simultaneously in order to take advantage of all market opportunities. This is of course a difficult organisational task because the market segments dealt with using various marketing procedures have to be carefully delimited from each other. Secondly, within the framework of the single insurance market, especially in case of commercial and industrial business, the independent professional brokers will have certain advantages; for they are the only ones able to make the Europe-wide range of insurance products transparent to customers and to help them make the difficult choice of the "best offer".

For the internal organisation of European insurers, a further forecast is possible. Because of the growing trend to turn to the customer and the growing importance of insurance covers encompassing several classes of business, the way that insurers are organised will shift away from the traditional product orientation based on different classes of business and move more and more towards a customer orientation. In particular, the organisation of business with industrial and commercial enterprises will gradually be separated from that of business with private households. This is a lenghty reorganisation process because not only practical problems must be solved but there will have to be changes in the traditional mentality found in insurance companies.

\section{Conclusions: Uniform or differentiated corporate strategy of European insurers?}

The movements which have occurred - and are still occurring - as a result of the single insurance market and other recognisable changes on the European insurance scene raise the question as to whether the corporate strategy of European insurers will be roughly the same or different. All in all, the strategic options described and the assessments made in respect of them lead to the prediction that a clearly differentiated corporate strategy will develop. The traditional old structures are being questioned, the elements of corporate policy are being re-examined and re-defined, and new structures will emerge. But even these will be different because European insurance will not present a uniform picture but will show great variety.

In theory, this process should lead to the emergence of the following types of European insurers, who will shape the picture of the future. If the guiding principles of corporate strategy are taken to be: 
- the extent of internationalisation and the decision to operate nationally or locally,

- and the degree of generalisation or specialisation with regard to customer groupings, with the corresponding consequences for the classes of insurance transacted,

then a matrix of possible insurer types can be developed and an estimate made of its probable extent (see Table 1).

Type 1a of the large and very-large general insurance company operating worldwide will no doubt gain in importance compared with the current situation. The number of such international insurers will not be high, of course, but their market share will be considerable. In particular, this area will continue to be the preserve of insurers with high financial strength which are already very large now. The importance of companies of this type will also grow as a result of further acquisitions and mergers.

Type $2 \mathrm{a}$ of the general insurer operating Europe-wide will probably not be very widespread, because the borders of the EC or Europe are artificial for internationalisation strategies and only facilitate certain aspects of market access. For that reason, Type 3 a with selective internationalisation is likely to attain greater importance. This type of insurer does not operate everywhere in the world or in Europe but only in countries with attractive markets or ones in which the home customers have special interests. Such selective internationalisation is also focussed on markets in Eastern Europe, the Far East and North America.

Type $4 \mathrm{a}$, the general insurer operating nationally or locally, will also decline in importance as purely national business with industrial clients loses weight; this business segment will ultimately consist only of the risks of small and medium-sized companies whose insurance policies are arranged more in accordance with the principles of privatecustomer business than with those of industrial and commercial business.

Insurers who specialise heavily in industrial and commercial business with large companies will be unable to avoid tendencies towards internationalisation in cases where their customers are themselves showing increasing internationalisation. Types $1 \mathrm{~b}, 2 \mathrm{~b}$ and $3 \mathrm{~b}$ will therefore be found more often than the purely national industrial insurer described as Type $4 \mathrm{~b}$. If only selected segments of the company-client business sector are to be worked, for example as special insurers for specific industries, then there the national insurer $(4 \mathrm{c})$ who knows his customers' problems particularly well will predominate.

By far the largest number of all insurers will probably confine themselves to business with private customers, as this is an area which promises the highest growth and is the most profitable in most countries (except very often Motor insurance). Limiting business to private customers will not necessarily lead to internationalisation. The national insurer type (4d) is likely to predominate here. This really holds true where operations are confined just to specific market segments (Type 4e), for examplc insurance for certain professions. It is, for instance, highly unlikely that health insurance for vicars will be internationalised. But this is not to say that insurers of private customers will not become active in neighbouring countries with close economic and legal relations (Type 3d).

The matrix shows nothing more than a rough prediction of the different types likely to emerge among European insurers. Polarisation into three basic types can be seen: the large international general insurer, the international industrial insurer who will probably decline in importance, and - by far the most predominant type - the primarily national insurer doing business with private customers. 


\section{A few remarks on the Spanish insurance market}

In the final part of my talk I shall deal with a number of particular aspects of the Spanish insurance market. This will be done from a foreigner's point of view or, to be more precise, from the point of view of a European who does not know the situation from his own experience. How can the considerations in respect of the corporate strategy of European insurers be put into concrete form for the Spanish market? What conclusions can be drawn for the position of the Spanish insurance industry in the single market of 1993 ?

In recent years, the Spanish economy has been characterised by an extraordinary growth rate which is also expected to continue over the next few years. The industrial sector in particular is growing rapidly. Many foreign companies are setting up production facilities in Spain because adequate resources are available at comparatively favourable cost. The contributions to the national product of the three sectors agriculture, industry and services are changing rapidly in favour of the last two, a trend which may possibly lead to major problems in the traditional economic and social structure, in particular through a process of polarisation into "rich" industrial areas and "poor" agricultural ones. The problem of inflation usually associated with strong growth is also of increasing importance.

For insurance business various conclusions may be drawn. The insurance industry must adapt its product range to follow the structural change. In spite of coinsurance available the insurance of new and growing industrial risks can lead to problems of capacity both with individual insurers and in the market as a whole - problems which have to be solved either through an increase in national capacity or through the increased use of international reinsurance. As national product grows, there is also an increase in the mass income of private households and with it in the volume of insurance demand and the income available for paying premiums. It is therefore basically a question of, if possible, developing privatecustomer business and industrial business simultaneously and proportionally, in order to obtain better conditions for the expansion of insurance portfolios.

Compared with the rest of the EC, the Spanish insurance industry has a number of peculiarities. The volume of business has grown considerably - both nominally and in real terms - in recent years and is also seen as capable of further expansion in the future. European insurers therefore see the Spanish market as being very attractive. However, when the prospects for growth are being analysed, single premium business in the life assurance sector, which will rather decrease in the future, will have to be assessed separately.

A special feature of the Spanish insurance industry is the high number of insurers, which means that the average size of individual insurance companies (and even the large ones) lies well below the EC average. The market shares of the individual insurers are also relatively small as a result. Many insurers operate only in individual segments of the market as a whole. A considerable amount of concentration has in fact taken place in recent years. A further reduction in the number of insurers is to be expected, so that, as firms grow bigger, know-how will be boosted, the ability to balance the risks in insurance portfolios will increase, and progress in the cost-effective transaction of insurance business will be achieved. This concentration is being promoted by foreign interest in the acquisition of Spanish insurers; for both takeover activities and the defence reactions they trigger often lead to reorganisation and restructuring measures within the whole industry. Here it should be borne in mind that a considerable number of Spanish insurance companies are already owned by foreigners or by Spanish banks. 
The insurance products usual on the Spanish market also have a number of distinctive features. This is particularly true as far as the distribution of multi-risk and "all risk" policies is concerned, the advantages of which for the customer have already been mentioned, as have the problems they give rise to for insurers. Possibly this form of product with its inherent calculation difficulties is the reason why premium levels are falling rapidly as a result of competition and problems of profitability are arising in the property insurance sector. In view of the heavy losses in the Spanish motor insurance sector - a typical phenomenon in countries where car ownership is growing apace - the high growth potential of the Spanish market would have to be weighed against declining profit expectations in any assessment of attractiveness.

One interesting feature of the Spanish insurance scene is a state consortium, vested with monopoly rights, which provides cover in respect of natural hazard and certain political risks. Because of the prohibition on monopolies under EC law, it is possible that this system may not be continued or, if continued, only with modifications. Owing to Spain's particular geographical location, the natural-hazard risk is somewhat higher than average (especially as far as storms and floods are concerned), so that insurance against damage caused by natural hazards constitutes an important individual problem. From the point of view of insurance theory, it is extremely difficult to organise insurance against natural hazards in a way that works competitively on the basis of free market forces. For where there is free competition, experience shows that antiselection of particularly hazardous risks occurs, leading to insufficient capacity for major losses. The pooling of risks involving natural hazards is therefore quite effective. This does not automatically have to be associated with a state monopoly if private underwriters are also involved in the pool and bring their business into it.

As far as corporate strategy is concerned, what needs and options can be deduced for Spanish insurers from the present situation and further expectations? The most obvious strategy is to give the existing insurance industry a new structure that complies with the new tasks arising from the changes in the Spanish economy. What has been mentioned is consolidation by concentrating on fewer but larger insurers with a higher capacity for industrial risks, associated with a gain in know-how in underwriting and marketing, and in the handling of contracts and claims settlement, i. e. largely in the whole range of services. The existing strength of Spanish insurers should be developed in this connection and their weaknesses eliminated, possibly with the help of foreign know-how.

There are various ways in which foreign insurers can assist in developing Spanish ones. One way is the transfer of know-how from international reinsurers who are less interested in acquiring Spanish direct insurers than in doing business with them.

Another way is for the Spanish direct insurance market to be largely opened up - which has already been done - to all interested foreign insurers wishing either to set up their own branches of subsidiaries or to acquire Spanish insurers. In this way, integration of the Spanish insurance industry into the single market would be particularly rapid, though of course increasing influence from abroad would have to be accepted.

It is not possible for a foreign theoretician to weigh such strategic alternatives against each other. If the "all business is local" principle also applies to Spanish business, however, it should be possible to retain and further develop the national characteristics of Spanish insurance business and thus also of Spanish insurers. 
Spanish insurers' own strategies for expansion into foreign markets are so far rather thin on the ground. This points to a thoroughly and adapt the Spanish market, not for expanding business into lesser-known markets. It should still be borne in mind though even today that the strong development of Spanish industry could very quickly lead it to expand abroad, so that industrial business with large Spanish firms would require international insurance covers. Therefore arrangements ought to be made for this right now.

Within the framework of the EC, the Spanish insurance industry may have a special task to fulfill, namely a bridgehead function in countries where Spanish is spoken and where there is a strong leaning towards Spanish culture and mentality - that is to say the countries of Central and South America in particular. Spain might also have another bridgehead role to play in the countries of North Africa, which for most European insurers (apart from a few French ones) are largely unknown territory.

However the Spanish insurance industry fulfils its tasks in the EC and beyond in the worldwide association of all insurers, the coming years will be a fascinating mixture of dynamism in economic affairs, of risks and opportunities, of successes and failures. To all the Spanish insurers present today, my wish is that you may always be on the side of opportunity and success and, in general, will remain under the spell of this fascination.

\section{BIBLIOGRAPHY \\ Corporate strategy of insurers}

BENÖLKEN, H.: Strategische Planung im Versicherungsunternehmen I bis IV, in: Versicherungswirtschaft, 1984, pp. 302-308, 379-384, 440-446, 510-514.

BÜCHNER, G.: Unternehmenspolitik, in: Handwörterbuch der Versicherung, Karlsruhe 1988, pp. 925-930.

CUMMINS, J. D. (Publisher): Strategic Planning and Modeling in Property-Liability Insurance, Boston, Dordrecht, Lancaster 1985.

FARNY, D. and KIRSCH, W.: Strategische Unternehmenspolitik von Versicherungsunternehmen, in: Zeitschrift für die gesamte Versicherungswirtschaft, 1987, pp. 369-404.

HALLER, M.: Die Versicherungswirtschaft vor strategischen Änderungen, in: Versicherungsrundschau, 1983, pp. 129-152.

HALLER, M.: Insurance 2000: International Tendencies and Strategic Options, in: Internationalität der Versicherung, Festgabe für Marcel Grossmann, St. Gallen 1984, 363-385.

KLEYBOLDT, C.: Versicherungsmanagement im Wandel, in: Versicherungswirtschaft 1986, pp. 1380-1394.

LÜNGER, R.: Marktveränderungen in der Versicherungswirtschaft? St. Gallen, 1986

MUTH, M. (Publisher): Mit Sicherheit gewinnen. Trends und Zukunftsaufgaben im VersicherungsManagement, Karlsruhe, 1982.

PRÖBSTL, W.A.: Strategische Unternehmensführung in der Versicherungswirtschaft, Karlsruhe, 1985.

WALKER, P. B.: Strategic Management: New Tool for Insurers, in: Best's Review, Property/Casualty Insurance Edition, 1981/82, No. 11, pp. 34-36, 107-112, and No. 12, pp. 36-30, 92.

ZECH, J.: Unternehmensstrategien vor dem Hintergrund des europäischen Binnenmarkts, in: Assekuranz im Wandel, Karlsruhe 1989, pp. 139-155. 


\section{Internalisation with particular reference to EC issues}

BAADENHOOP, J.: Binnenmarkt der Versicherungen bis 1992?, in: Versicherungswirtschaft, 1987, pp. 622-635.

BIAGOSCH, A.: Der europäische Versicherungsmarkt 1992 aus rechtlicher und praktischer Sicht, in: Versicherungsrundschau, 1988, pp. 369-377.

BICKELHAUPT, D. L. and BAR-NIV, R.: International Insurance. Managing Risk in the World, New York 1983.

CARTER, R. L.: Multinational Insurance Companies, Nottingham 1975.

DAVENPORT, N.: Sleepers Awake! in: The Review, 1988, No. 9, pp. 31-35.

FARNY, D.: Auslandsaktivitäten deutscher Versicherungsunternehmen, in: Versicherungswirtschaft, 1984, pp. 30-44.

FARNY, D.: Erwartungen europäischer Versicherer an den Binnenmarkt, in: Zeitschrift für die gesamte Versicherungswissenschaft, 1989, pp. 67-106.

GAMPER, R.: Probleme eines international tätigen Versicherers, in: Versicherungsrundschau, 1980, pp. 125-139.

HAASEN, U.: Internationale Versicherungsmärkte: Freier Zugang - freier Wettbewerb? in: Versicherungswirtschaft, 1987, pp. 26-35.

HOEH, T. J.: Building a Global Presence, in: Best's Review, Property/Liability Insurance Edition, 1983/84, No. 9, pp. 36-38, 42.

JANNOTT, H. K. and GERATHEWOHL, K.: Probleme des internationalen Risikoausgleichs, in: Zeitschrift für Versicherungswesen, 1984, pp. 521-526. Also: An International Balance, in: The Review vom 11. 3. 1985, pp. 22-27.

LOUBERGÉ, H.: A Portfolio Model of International Reinsurance Operations, in: Journal of Risk and Insurance, 1983, pp. 44-60.

MÜLlER-GOTTHARD, E.: Chancen und Risiken im Auslandsgeschäft, in: Versicherungswirtschaft, 1984, pp. 45-54.

PADOA, F.: L'Assicurazione Internazionale, Milano 1983.

PETRONI, G.: Controlling Overseas Insurance Subsidiaries, in: Long Range Planning, 1989, No. 116 , pp. 106-114.

PFENNIGSTORF, W.: Doing Business Abroad, Chicago 1981.

RATCLIFF, A.: Strategische Aspekte für die internationale Expansion eines Versicherungsunternehmens, in: Zeitschrift für Versicherungswesen, 1988, pp. 137-142.

REUTER, F.: Grundzüge der Internationalen Unternehmenspolitik des Versicherungsunternehmens, Berlin 1983.

SCHMIDT, R.: Auslandstätigkeit von Versicherungsunternehmen, in: Versicherungsrundschau, 1980, pp. $140-154$.

SCHMIDT, R.: Versicherungswirtschaft im EG-Binnenmarkt, in: Zeitschrift für die gesamte Versicherungswissenschaft, 1989, pp. 51-65.

SCHMOECKEL, J.: Erfolgskontrolle von Auslandsinvestitionen der Versicherungsunternehmen, Dissertation Köln 1982.

SCHLUDE, H.: Die Entwicklung der Versicherung in der EG im Hinblick auf die Schaffung des einheitlichen Binnenmarktes, in: Versicherungsrundschau, 1989, pp. 193-203.

SCHROATH, F. W.: Analysis of Foreign Market Entry Techniques for Multinational Insurers, Dissertation University of South Carolina 1987. Kurzfassung in: Geneva Papers of Risk and Insurance, 1988, No. 49, pp. 361-376.

SCHÜRPF, W. E.: Der EG-Binnenmarkt: Business as Usual oder Strukturbruch für die Rückversicherung? in: Versicherungswirtschaft, 1990, pp. 32-36.

STREMITZER, H.: Internationalität des Versicherungsgeschäfts, in: Handwörterhuch der Versicherung, Karlsruhe, 1988, pp. 307-310.

WHITE, M. D.: Why go Global? in: Best's Review, Life/Health Insurance Edition, 1989/90, No. 6, pp. $22-24,114$. 


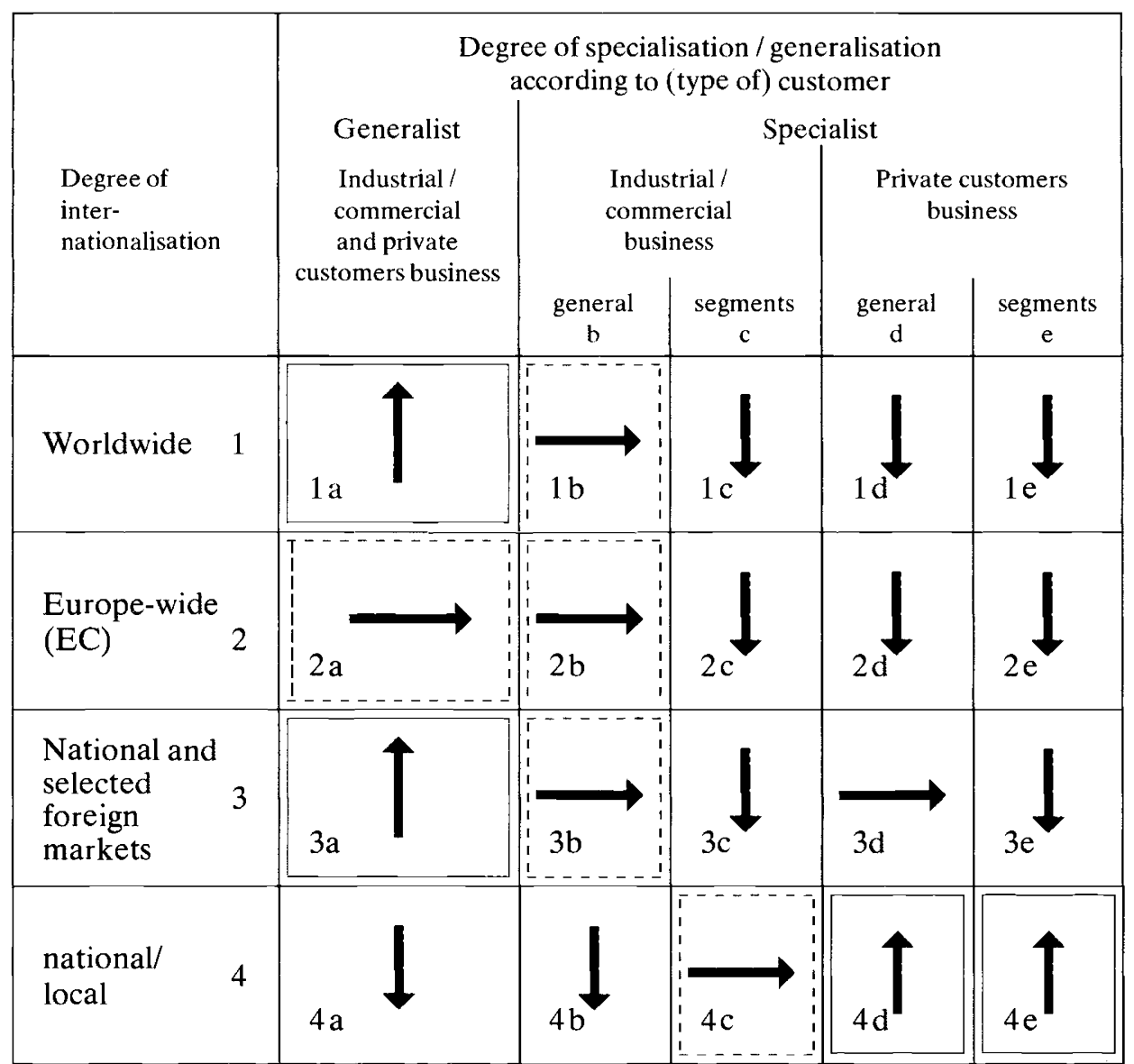

C Considerable and/or growing importance of the following types of insurers:

Type 1 a: (very) large general insurers operating worldwide

Type 3a: general insurers operating nationally and in selected countries

Type $4 \mathrm{~d}$ : insurers operating nationally in the private customer sector

Type $4 \mathrm{e}$ : insurers operating nationally in selected segments of the private customer sector

\footnotetext{
$\longrightarrow$ moderate and/or constant importance

$\downarrow$ little and/or declining importance
}

Table 1: Forecast of the types of European insurers to emerge 